This is an Accepted Manuscript of an article published by Edinburgh University Press in Edinburgh Law Review, Volume 24 Issue 2, Page 289-296. The Version of Record is available online at: http://www.euppublishing.com/doi/abs/10.3366/elr.2020.0635.

\title{
ENVIRONMENTAL GOVERNANCE IN SCOTLAND AFTER EU EXIT: THE STATE OF PLAY
}

\author{
Annalisa Savaresi*
}

\section{A. INTRODUCTION}

It has long been known that EU exit would affect environmental law-making and enforcement in Scotland, as well as in the rest of the UK. It may therefore come as a surprise that, almost four years since the EU referendum, several environmental governance questions remain unresolved. The reasons for this state of affairs are twofold.

On the one hand, the magnitude of the gaps in environmental governance associated with EU exit can scarcely be overestimated. As I have already explained in this journal, ${ }^{1}$ environmental governance in the UK presently relies upon a several EU arrangements, from the making of legislation, and the review of implementation and enforcement, to financial support and cooperation activities. If unmitigated, this loss of EU governance arrangements would result in gaps on a range of matters, such as air pollution and climate change, waste, water, and chemicals, both at the Scottish and at the UK level. EU exit therefore requires that these governance arrangements be somehow replaced.

On the other hand, the political debacle over EU exit has sucked energy out of the complex technical decision-making process over how to address these environmental governance gaps. As a result, after the UK formal exit from the EU on 31 January, a series of cross-cutting environmental governance questions remain unanswered, namely:

- How to replace environmental governance arrangements that presently depend on EU institutions - such as emissions trading and chemicals regulation;

- how to enable Scotland to 'keep pace' with EU environmental standards, given that the UK Government does not intend to do the same;

- how to allocate law-making and enforcement powers presently exercised by the EU between UK and devolved administrations after exit;

- how to replace the EU's review and enforcement powers over UK public authorities;

- whether and how to maintain the role of EU environmental law principles in future policy making.

This article considers these questions in turn, analyzing and assessing the state of play of environmental governance in Scotland after EU exit. It looks at action already taken by the

\footnotetext{
* Senior Lecturer, Environmental Law, University of Stirling. This article draws on the author's work as Academic Fellow with the Scottish Parliament Information Centre, and more specifically on the report: Annalisa Savaresi, 'Environmental Governance in Scotland after EU Exit' (Scottish Parliament Information Service 2020).

${ }^{1}$ Annalisa Savaresi, 'The Impact of Brexit on Environmental Protection in Scotland: Some Early Reflections' (2017) 22 Edinburgh Law Review 115.
} 
Scottish Government, in light of developments at the UK level. The conclusions highlight issues for further consideration.

\section{B. FUTURE ALIGNMENT WITH EU ENVIRONMENTAL STANDARDS}

The Scottish Government has expressed its ambition to maintain close ties with the EU, and to continue to 'keep pace' with EU law after exit. ${ }^{2}$ Whether Scotland will manage to realise this ambition, however, largely depends on the future UK-EU relationship and on measures that may be adopted in order to avoid regulatory fragmentation after exit.

Presently, the future relationship between the UK and the EU remains to be determined. The non-binding Political Declaration attached to the Withdrawal Agreement provides for the negotiation of a Free Trade Agreement between the EU and the UK. ${ }^{3}$ Little is presently known on the shape and guise of this agreement.

Comparatively more information is available on the likely degree of the UK's future alignment with EU environmental standards. While the 2018 Draft EU Exit Agreement explicitly committed the UK to continued regulatory alignment with the $\mathrm{EU},{ }^{4}$ such language does not features in the Withdrawal Agreement concluded in October 2019. ${ }^{5}$

The Scottish Government ${ }^{6}$ and civil society organisations have raised concerns over this changed position and the fact that environmental law will come 'under sustained deregulatory pressure, including from those seeking to strike trade deals, for example with the US'.?

The Scottish Parliament did not support the Withdrawal Agreement, which was nevertheless enshrined the European Union Withdrawal Act of 2020. In 2019, the Scottish Government has announced its plans to introduce a Continuity Bill that will enable the Scottish Parliament to 'keep pace' with EU law in devolved areas, including the environment. ${ }^{8}$

\footnotetext{
${ }^{2}$ Scottish Government, 'Scotland's Place in Europe: Our Way Forward’ (2018).

${ }^{3}$ Political Declaration Setting out the Framework for the Future Relationship between the European Union and the United Kingdom (2019).

${ }^{4}$ Draft Agreement on the Withdrawal of the United Kingdom of Great Britain and Northern Ireland from the European Union and the European Atomic Energy Community, as Agreed at Negotiators' Level on 14 November 2018 (2018).

${ }^{5}$ Agreement on the Withdrawal of the United Kingdom of Great Britain and Northern Ireland from the European Union and the European Atomic Energy Community (2019).

${ }^{6}$ Declaration by Cabinet Secretary Roseanna Cunningham, as reported in Scottish Parliament, 'Official Report: Environment, Climate Change and Land Reform Committee 29 October 2019'.

${ }^{7}$ Greener UK and Wildlife and Countryside Link. (2019). Briefing for Commons Second Reading of the Environment Bill.

${ }^{8}$ Scottish Government, 'Government’s Programme for Scotland 2019-2020’.
} 
Scotland's ability to keep pace with EU environmental standards will however critically depend also on measures that may be adopted to avoid regulatory fragmentation and safeguard the integrity of the UK internal market.

Since devolution, EU membership has provided an element of commonality in environmental standards across the UK. With the removal of the EU law frame, this commonality may be progressively lost, due to the adoption of diverging standards on devolved matters over time. It is not yet known what measures may be adopted in order to safeguard the integrity of the UK internal market. These measures however may well affect the ability of the Scottish Government to align with EU law in future and its exercise of competence in environmental matters. Challenges are more likely in areas that presently heavily rely on EU governance arrangements. For example, should the UK decide to pursue a different approach to chemicals regulation to that of the EU, the Scottish Government's ambition to continue to align with EU standards in this area could be frustrated. In this connection, it is important to recall that UK businesses will have to continue to comply with EU standards concerning products in order to export into the EU single market. Therefore, trade with the EU will require continued alignment, at least on products. ${ }^{9}$

\section{ALLOCATION OF REPATRIATED GOVERNANCE POWERS}

The repatriation of powers presently exercised by the EU raises fundamental questions concerning where these powers will fall. The UK Government estimates that between 107 and 111 areas of EU law fall within the devolved competence of the Scottish Parliament. ${ }^{10}$ The UK Government has identified 12 policy areas which it considers reserved, but which are subject to ongoing discussion with devolved administrations.

The 2018 European Union (Withdrawal) Act $^{11}$ introduced powers for the UK Government to apply a temporary 'freeze' on devolved competence in specified areas - which the Scottish Government described as a 'power curb'. ${ }^{12}$ Until September 2019 at least, the UK Government had not frozen devolved competence, and the Scottish and Welsh Governments have committed not to pursue policy divergence, where they agree frameworks are necessary or while discussions are ongoing. ${ }^{13}$

The UK and devolved governments have agreed in principle to work together to develop common frameworks in some areas which are currently governed by EU law and which are of competence of the devolved administrations or legislatures. These frameworks are meant

\footnotetext{
${ }^{9}$ See e.g. Joanne Scott, 'From Brussels with Love: The Transatlantic Travels of European Law and the Chemistry of Regulatory Attraction' (2009) 57 The American Journal of Comparative Law 897; Savaresi (n 2).

${ }^{10}$ UK Government. (2019). Revised Frameworks Analysis: Breakdown of areas of EU law that intersect with devolved competence in Scotland, Wales and Northern Ireland.

${ }^{11}$ European Union (Withdrawal) Act 2018.

12 ‘Scottish Government Press Release: Devolved Power Curb ‘should Be Repealed’' (13 November 2018).

${ }^{13}$ UK Government, Cabinet Office. (2019). The European Union (Withdrawal) Act and Common Frameworks 26 June 2019 to 25 September 2019.
} 
to provide long term policy arrangements to be implemented by the end of the transition period. ${ }^{14}$

The reason for developing such common frameworks is twofold. On the one hand, there is a desire to secure a level of coherence and to avoid regulator fragmentation within the UK. On the other, there is a need to ensure continued compliance with the UK international obligations after exit.

Even though environmental issues are devolved, the Scottish executive may not take any action, or fail to act, in way that is 'incompatible with international obligations'. ${ }^{15}$ After EU exit, the UK may be under pressure to accept to lower environmental standards than those of the EU, in order to agree new free trade agreements. So, while trade agreements may not prevent Scotland to adopt legislation keeping pace with EU environmental standards, they may engender a situation whereby Scotland would be at a competitive disadvantage for adopting more ambitious standards -for example on agriculture products- vis-à-vis the rest of the UK and its new trade partners.

This state of affairs entails that, while the Scottish Parliament can legislate on environmental matters at home, the Scottish Government may lack the authority to enter formal negotiations with international parties to address Scottish interests - such as, for example, fisheries - as this power is presently the exclusive prerogative of the UK Government. ${ }^{16}$ The Scottish Government has repeatedly expressed its frustration, asking to be treated as an 'equal partner' and assume the 'lead negotiating role' on issues where they have 'the majority interest. ${ }^{17}$

\section{REPLACEMENT OF EU REVIEW AND ENFORCEMENT POWERS OVER UK AUTHORITIES}

After the EU referendum, several experts identified the loss of the EU review and enforcement powers as a pressing concern. ${ }^{18}$ A 2018 expert report commissioned by the Scottish Government to identify gaps arising from EU exit, and options to address these ${ }^{19}$ suggested that, after EU exit, the existing review functions of public bodies in Scotland such as the Scottish Environmental Protection Agency and Scottish Natural Heritage - be expanded and reviewed. ${ }^{20}$ On enforcement, the report recommended that the EU's functions

\footnotetext{
${ }^{14}$ Cabinet Secretary for Government Business and Constitutional Relations, Michael Russell, evidence to the Finance and Constitution Committee, February 2019.

${ }^{15}$ Scotland Act 1998, schedule 58.

${ }^{16}$ Scotland Act 1998, schedule 5, s 7.

${ }^{17}$ See e.g. Cabinet Secretary for the Rural Economy, Fergus Ewing, evidence to the House of Lords, EU Energy and Environment Sub-Committee, September 2016.

${ }^{18}$ Scottish Universities Legal Network on Europe (n 20); UKELA, 'Brexit and Environmental Law. Enforcement and Political Accountability Issues’ (UKELA 2017).

${ }^{19}$ Scottish Government Roundtable on Environment and Climate Change, "Environmental Governance in Scotland after Brexit: Report” (Scottish Government 2018).

${ }^{20}$ Scottish Government Roundtable on Environment and Climate Change (n 21).
} 
concerning scrutiny and assessment of compliance, investigation and judicial scrutiny over the activities of public authorities be replaced. The report suggested to either expand the prerogatives of existing national bodies, or to establish a new statutory body tasked with these functions. On judicial scrutiny specifically, the report proposed an independent panel to replace the functions performed by EU institutions in the short term; and the establishment of a dedicated body- such as an environmental court - in the long run.

A 2019 public consultation gathered evidence on future arrangements for environmental governance after EU exit. ${ }^{21}$ The consultation responses converged on the need to replace the EU Commission's role in receiving complaints from the public about compliance with environmental law. ${ }^{22}$ The responses supported interim arrangements, and more long term solutions, such as an ad hoc independent body or watchdog. Some specifically advocated for the establishment of an environmental court. ${ }^{23}$

The Scottish Government had already held a public consultation on whether to establish an environmental court in $2016 .{ }^{24}$ That consultation was aimed to address concerns over Scotland's compliance with obligations on access to justice under the Convention on Access to Information, Public Participation in Decision-Making and Access to Justice in Environmental Matters. ${ }^{25}$ In 2017, the Scottish Government resolved not to establish a specialist court, but committed to keep the issue under review. ${ }^{26}$ The governance gaps associated with EU exit have nevertheless reopened the debate on ways to improve access to justice in environmental matters.

In October 2019, the Cabinet Secretary for Environment, Climate Change and Land Reform announced the establishment of an interim advisory panel to ensure the 'maintenance of environmental standards and implementation of environmental law in Scotland' in case of a no deal exit. The new interim advisory panel would 'replicate as far as possible, the role of the EU Commission in scrutinising environmental compliance by the Scottish Government and other public bodies: ${ }^{27}$ Specifically, the panel would undertake fact finding and analyse work on key areas of compliance with environmental law; advise Scottish Ministers and; seek ehanges to rectify any issues. The panel would also deal with pending infringement cases before EU institutions, although it is yet not clear what power the panel will have in this

\footnotetext{
${ }^{21}$ Environmental principles and governance after Brexit: consultation (16 February 2019).

${ }^{22}$ Environmental principles and governance after Brexit: responses to consultation (4 October 2019).

${ }^{23}$ Scottish Environment Link, 'Environmental Governance: Effective Approaches for Scotland Post-Brexit' (2019).
}

${ }^{24}$ Developments in environmental justice in Scotland. A consultation (March 2016).

${ }^{25}$ See e.g. Aarhus Convention, Compliance Committee. (2017). Compliance by the United Kingdom of Great Britain and Northern Ireland with its obligations under the Convention. ${ }^{26}$ Developments in environmental justice in Scotland: Consultation analysis and Scottish Government response
(2017).

${ }^{27}$ Scottish Government. (2019). Safeguarding Environmental Standards. 
connection. The Scottish Government is yet to present proposals for long-term enforcement arrangements.

The UK Government has instead already proposed to establish a 'commission-like body' to oversee 'all environmental law'. ${ }^{28}$ The Environment Bill introduced in January 2020 makes provisions for the establishment of an Office for Environmental Protection (OEP), as an independent non-departmental public body, expected to employ up to 120 staff. The OEP would provide scrutiny and advice functions, and monitor progress in accordance with the UK Government's domestic environmental plans and targets. It would replace the role of the European Commission in respect of environmental compliance, engaging with public authorities to manage compliance issues relating to environmental law. Legal proceedings would only be taken as a last resort or in urgent cases.

Environmental NGOs have welcomed the establishment of the OEP but lamented that the Bill does not give it 'a sufficiently wide remit to ensure adequate environmental governance or to properly fulfil its potential.' ${ }^{29}$ Therefore, they called for a move away from 'traditional judicial review', and for the recognition of the important role of civil society in ensuring compliance with environmental law. ${ }^{30}$ At the same time, Scotland's Cabinet Secretary for Environment, Climate Change and Land Reform, has expressed frustration over lack of clarity over issues on which the OEP might be able intervene in Scotland. ${ }^{31}$

\section{E. THE ROLE OF EU ENVIRONMENTAL LAW PRINCIPLES IN FUTURE POLICY MAKING}

Environmental law is underpinned by a set of principles, which may be defined as policy statements 'concerning how environmental protection and sustainable development ought to be pursued'. ${ }^{32}$ Environmental principles typically concern:

- how the law is made (for example, through public consultation and participation),

- how it is enforced (for example, by guaranteeing access to justice to certain groups or interests), and

- its substantive content (for example, when principles are incorporated into legislative instruments or into the design of regulatory structures and processes).

EU environmental law hinges on four core principles, which feature in a host of EU instruments and policy documents. Article 191.2 of the Treaty on the Functioning of the

\footnotetext{
${ }^{28}$ Michael Gove MP, Secretary of State, Department for Environment, Food and Rural Affairs, Oral Evidence, Environmental Audit Committee, 1 November 2017.

${ }^{29}$ See $n 7$

${ }^{30}$ Ibid.

${ }^{31}$ See n 6.

${ }^{32}$ Fisher, E., Lange, B., \& Scotford, E. (2013). Environmental Law: Text, Cases, and Materials (Oxford University Press).
} 
European Union (TFEU) singles out the principles of prevention and precaution; the polluter pays principle; and the principle that environmental damage should be rectified at source.

These four principles are not an EU 'invention', but rather are a common feature of mature environmental law and policy all over the world. ${ }^{33}$ In spite of their 'universal and foundational' nature, environmental law principles perform very different legal roles in different countries. ${ }^{34}$ The issue is therefore not whether these principles ought to remain part of UK/Scottish environmental law and policy into the medium and long term, but how they will do so.

The current regime is founded on the inclusion of environmental principles in the EU treaties, as well as in EU environmental law instruments. These principles require legislators, policymakers, regulators as well as EU institutions to have regard to and implement them, and failure to do so appropriately may be sanctioned by the CJEU. ${ }^{35}$

Upon EU exit, public authorities in the UK will no longer be required to ensure that EU environmental principles guide law and policy-making. Both the UK and the Scottish Governments have vowed to ensure that EU environmental principles continue to be enshrined in law. The modalities of such inclusion have been the subject of much debate, but so far no measures have been adopted by either government in this regard.

Responses to the 2019 Scottish Government's public consultation supported the introduction of a specific duty for Ministers to uphold EU environmental law principles in the formation of policy. Respondents suggested that the duty should be enshrined in legislation, that it might cover public authorities other than Ministers, and activities other than the formation of policy. Some respondents recommended that principles not mentioned in the consultation document -such as for example, sustainable development, integration or non-regression- be included in the scope of the duty.

The Programme for Government for 2019-2020 announced that the Continuity Bill would include measures 'to ensure that we maintain the role of environmental principles'. Cabinet Secretary Cunningham has made it clear that these principles would only encompass those enshrined in Article 191.2 TFEU. ${ }^{36}$

Conversely the Environment Bill introduced before the UK Parliament in January 2020 provides for a 'policy statement on environmental principles', including also the integration principle. ${ }^{37}$ The Bill envisions a statement explaining 'how the environmental principles should be interpreted and proportionately applied by Ministers of the Crown when making policy.'

\footnotetext{
${ }^{33}$ See for example E Scotford, Environmental Principles and the Evolution of Environmental Law (Hart 2017), 9. 
The stated intention of both the UK and Scottish Government is therefore a significant departure from the current position. ${ }^{38}$ A less robust legal underpinning for environmental principles would increase the discretion of domestic decision-takers, policymakers and regulators. After exit, this enhanced discretion will in all likelihood be coupled with far greater lobbying from vested interests and stakeholders than is the case at the moment. This may result over time in a relative loss of certainty and consistency in the interpretation and application of the principles, and the emergence of more ad hoc, piecemeal and arguably less coherent/effective systems of environmental protection. ${ }^{39}$

\section{F. KEY ISSUES FOR FUTURE CONSIDERATION}

This article has taken stock of the key issues raised by EU exit for environmental governance in Scotland, summarising the state of play. It found that the degree of Scotland's future alignment with EU environmental standards will depend on the future UK-EU relationship, and on the allocation of repatriated powers after exit.

The debate concerning the allocation of repatriated EU powers between the UK and devolved administrations remains ongoing. This allocation requires political agreement on who will be doing what after EU exit, and pursuant to which rules. EU exit however also provides an opportunity to go beyond the status quo and its discontents. Scotland could for example request greater devolved powers to enter into international agreements addressing specific Scottish interests, such as fisheries. ${ }^{40}$

Equally, work to replace extant EU environmental governance arrangements - such as emissions trading and chemicals regulation - is underway and remains ongoing. While both the UK and the Scottish Governments have agreed to replace the EU review and enforcement powers over UK public authorities, and to maintain the role of EU environmental law principles in future policy making, solutions in both connections are still under discussion. Much uncertainty therefore remains, and much political and technical work remains to be done in order to bridge the gaps in environmental governance left by EU exit, on both sides of the border.

38 See e.g. Annalisa Savaresi and Gavin FM Little, 'Written Submission from Annalisa Savaresi and Gavin MacLeod Little,' (2018); Greener UK and Wildlife and Countryside Link, 'Briefing for Commons Second Reading of the Environment Bill' (2019).

${ }^{39}$ Ibid.

${ }^{40}$ As suggested for example in Savaresi (n 3); and Jacques Hartmann, 'The Faroe Islands: Possible Lessons for Scotland in a New Post-Brexit Devolution Settlement' (2019) 44 European Law Review 110. 